\title{
Jahani Salt Diapir, Iran: hydrogeology, karst features and effect on surroundings environment
}

\author{
Mahmoud Abirifard ${ }^{1}$, Ezzat Raeisi ${ }^{1^{*}}$, Mehdi Zarei ${ }^{1}$, Mohammad Zare ${ }^{1}$, Michal Filippi ${ }^{2}$, \\ Jiři Bruthans ${ }^{3}$, and Christopher J. Talbot ${ }^{4}$
}

${ }^{1}$ Department of Earth Sciences, College of Sciences, Shiraz University, Shiraz, Iran

${ }^{2}$ Institute of Geology of the Czech Academy of Sciences, v. v. i., Rozvojová 269, Praha 6, Czech Republic

${ }^{3}$ Faculty of Science, Charles University, Albertov 6, 12843 Praha 2, Czech Republic

${ }^{4}$ Hans Ramberg Tectonic Laboratory, Uppsala University, 752 36, Uppsala, Sweden

\begin{abstract}
The Jahani Salt Diapir (JSD), with an area of $54 \mathrm{~km}^{2}$, is an active diapir in the Simply Folded Belt of the Zagros Orogeny, in the south of Iran. Most of the available studies on this diapir are focused on tectonics. The hydrogeology, schematic model of flow direction and hydrochemical effects of the JSD on the adjacent water resources are lacking, and thus, are the focus of this study. The morphology of the JSD was reevaluated by fieldwork and using available maps. The physicochemical characteristics of the springs and hydrometric stations were also measured. The vent of the diapir is located $250 \mathrm{~m}$ higher than the surrounding glaciers, and covered by small polygonal sinkholes (dolines). The glacier is covered by cap soils, sparse trees and pastures, and contains large sinkholes, numerous shafts, several caves, and 30 brine springs. Two main groups of caves were distinguished. Sub-horizontal or inclined stream passages following the surface valleys and vertical shafts (with short inlet caves) at the bottoms of nearly circular blind valleys. Salt exposure is limited to steep slopes. The controlling variables of flow route within salt diapirs are the negligible porosity of the salt rocks at depth more than about ten meters below the ground surface and the rapid halite saturation along the flow route. These mechanisms prevent deep cave development and enforce the emergence points of brine springs with low flow rates and small catchment area throughout the JSD and above the local base of erosion. Tectonics do not affect karst development, because the distributions of sinkholes and brine springs show no preferential directions. The type of spring water is sodium chloride, with a TDS of $320 \mathrm{~g} / \mathrm{l}$, and saturated with halite, gypsum, calcite and dolomite. The water balance budget of the JSD indicates that the total recharge water is $1.46 \mathrm{MCM}$ (million cubic meter)/a, emerges from 30 brine springs, two springs from the adjacent karstic limestone, and flows into the Firoozabad River (FR) and the adjacent alluvium aquifer. The FR cuts through the northern margin of the salt diapir, dissolving the glacier salts at the contact with JSD, increasing the halite concentration of the 17.7 MCM/a of the FR from $100 \mathrm{mg} / \mathrm{l}$ to $12,000 \mathrm{mg} / \mathrm{l}$. This is a permanent process because the active glacier flows rapidly down the steep slopes into the river gorge from the nearby vent. The possible relocation of the FR channel would enhance the FR water quality, but disrupt the natural beauty of the diapir.
\end{abstract}

Keywords: $\quad$ salt diapir, brine spring, sinkhole, flow model, halite dissolution, salt karst Received 16 May 2017; Revised 2 October 2017; Accepted 4 October 2017

Citation: $\quad$ Abirifard M., Raeisi E., Zarei M., Zare M., Filippi M., Bruthans J. and Talbot C.J., 2017. Jahani Salt Diapir, Iran: hydrogeology, karst features and effect on surroundings environment. International Journal of Speleology, 46 (3), 445-457. Tampa, FL (USA) ISSN 0392-6672 https://doi.org/10.5038/1827-806X.46.3.2133

\section{INTRODUCTION}

A salt diapir is formed by an upward movement, from depths of more than $2.5-3 \mathrm{~km}$, caused by density differences between salt and its denser overburden where the stiffer overlying rocks are broken (Talbot et al., 2000). The extruded salt spreads over adjacent formations as "salt fountains", and gravity causes salt to flow downslope as "salt glaciers" (Kent, 1958, 1970) or "namakiers" (Talbot \& Jarvis, 1984). Numerous salt diapirs have been reported in Iran, the Persian Gulf coast region, the Dead Sea coast, Tunisia, Spain, the north German Plain, Albania, (Johnson, 1997; Bosák, et al., 1998; Talbot, 1998; Calaforra \& Pulido-Bosch, 1999; Hamlin, 2006; Lucha et al., 2008; RodriguezEstrella \& Pulido-Bosch, 2010), however, few are 
exposed at the land surface. In Iran, salt diapirs crop out in Semnan, Qom, Ghazvin, ChaharmahalBakhtiari provinces, and areas in southern Iran, (Talbot et al., 2009). About 130 salt diapirs emerge onto the surface in the south of Iran (Talbot \& Alavi, 1996).

The Jahani Salt diapir (JSD) extrudes in the south of Iran, $130 \mathrm{~km}$ southeast of Shiraz. The English translation of the Farsi name "Jahani" means "(salt) mountain of the Universe", referring to the beauty of this impressive salt mountain. This diapir is in direct contact with alluvium and karstic aquifers and the Firoozabad River (FR). The JSD is currently one of the most active salt diapirs of the Zagros Range. The Hormuz salt rises through an orifice with a diameter of $1.7 \mathrm{~km}$ from $4 \mathrm{~km}$ below sea level to $1,485 \mathrm{~m}$ above sea level and 1,000 $\mathrm{m}$ above the adjacent plain (Talbot et al., 2000). The glacier spreads over the marly Mishan Formation. The JSD surface is covered by cap soil rock (ca. 95\% of the surface) and salt exposures (ca. 5\%) based on the analysis of detailed aerial images, in combination with field mapping (Bruthans et al., 2006). Bare rock salt occurs only on the steep slopes of valleys and hills (slopes greater than $50^{\circ}$ ) and at the bottom and sides of some sinkholes (dolines) where the insoluble residue originating from the dissolved rock salt is repeatedly washed down (Bruthans et al., 2000).

Tayebi et al. (2013) prepared a lithological map of the JSD using Advanced Spaceborne Thermal Emission Reflection Radiometer (ASTER) and a MultiLayer Perceptron MLP neural network model. In their method, lithological units, including salt rock/salt affected-area, gypsiferous soil, limestone, sandstone and shale were distinguished. The salt-affected area is the region of salt deposition on the soil surface by runoff evaporation outside the JSD (Fig. 1).

The cap soil mainly originates from rock and mineral debris released by dissolution of the salt rock. It is mainly composed of gypsum, anhydrite, calcite, quartz and dolomite (Bruthans et al., 2008). Bruthans et al. (2008) classified the weathering residuum (cap soil) thickness into very thin, thin, medium and thick. The cap soil thickness is a critical factor since it controls the type, frequency and size of karst forms. Salt caves seldom originate in areas of bare rock salt, since runoff water reaches very rapidly saturation with respect to halite and then drains over the surface. It is the thickness and areal extent of the weathering residuum in the recharge area of the caves that controls the degree of karstification and cave development on JSD and elsewhere in Iranian salt karst terrains (Bruthans et al., 2000). The thickness and weight of the roof of salt with or without cap soil directly above the cave may influence intensity of breakdowns in shallow caves which are less stable compared to those developed at greater depth. The two most important geomorphological features affected by the thickness of the cap soil playing on the JSD are (for details see Bruthans et al., 2000, 2009): (a) Density and character of recharge points, which has a negative correlation with thickness of overburden. (b) Denudation rate of salt karst. Long-term annual denudation rates of salt exposures are estimated to be about $120 \mathrm{~mm} \mathrm{a}^{-1}$, while denudation rates of a thin cap soil are less than few $\mathrm{mm} \mathrm{a}^{-1}$ (Bruthans et al., 2006). Salt dissolution beneath thick overburdens is mainly concentrated into cave passages. Vegetation grows where the overlying cap soil is thicker than 2-3 m (Bruthans et al., 2008). Continuous grass covers cap soil thicker than $5 \mathrm{~m}$. These areas are seasonally inhabited by nomads who let their sheep graze there despite the lack of fresh water (except temporary pools of collected rain water), and the hazardous and unstable landscapes. Three solar evaporation basins have been constructed around the JSD to exploit the salt for industrial uses.

The tectonics and morphology of the salt diapirs of southern Iran have been investigated by Talbot (1979), Talbot \& Jarvis (1984), Talbot (1998), Bosák et al. (1999), and Bruthans et al. (2000). While the work of Bosák et al., (1999), covered the general morphology of several Zagros Zone salt diapirs, it did not investigate the Jahani Salt Diapir. The hydrogeology of several salt diapirs of southern Iran was studied by Raeisi et al. (1996), Sharafi et al. (2002), Zarei et al. (2011, 2012, 2013, 2014), Nekouei et al. (2016), Nekouei \& Zarei (2016), and Bruthans et al. (2017). In 2010, Zarei $\&$ Raeisi (2010b, 2010c) described the mechanisms of karst development and the flow directions of salt and groundwater on the Konarsiah Salt Diapir. The impacts of 62 salt diapirs on the adjacent karst and alluvium aquifers were studied by Zarei \& Raeisi (2010a) and Mehdizadeh et al. (2015). Zarei (2015) discussed the mechanisms and major factors that control the impact of salt diapirs on surrounding water resources.

Despite extensive studies on the geology and morphology of the JSD, the hydrogeology of this diapir has not previously been investigated. The objective of this research is to characterize hydrogeology and karst features of the JSD, namely:

(i) Sinkholes, caves and overall pattern of karstification.

(ii) Spring water flow rate and chemistry, both on the diapir and also flow of brine draining from the diapir over and into surrounding formations.

(iii) Determine the water resources of the JSD, the flow pattern of its surface and groundwater, and its effect on adjacent aquifers and surface waters.

\section{HYDROGEOLOGICAL SETTINGS}

The JSD is located in the Simply Folded Belt Zone of the Zagros Orogen. The details of the sedimentary sequence and the structural characteristics of the Zagros Zones are discussed by James \& Wynd (1965) and Falcon (1974). The formations present, in decreasing order of age, are the Upper Precambrian to Middle Cambrian Hormuz salt, Jurassic Surmeh limestone, Cretaceous Khami Group (Fahiylan limestone, Gadvan shale, Dariyan limestone), Cretaceous Kazhdumi shale, Cretaceous Sarvak limestone, Cretaceous-Tertiary Pabdeh-Gurpi shale and marl, Oligo-Miocene Asmari limestone, Tertiary Gachsaran marl and evaporites, Tertiary Mishan marl and shale, Tertiary Aghajari sandstone and marlstone, and Quaternary Bakhtiari conglomerate (Fig. 1 and Fig. 2). The Hormuz salt rises 


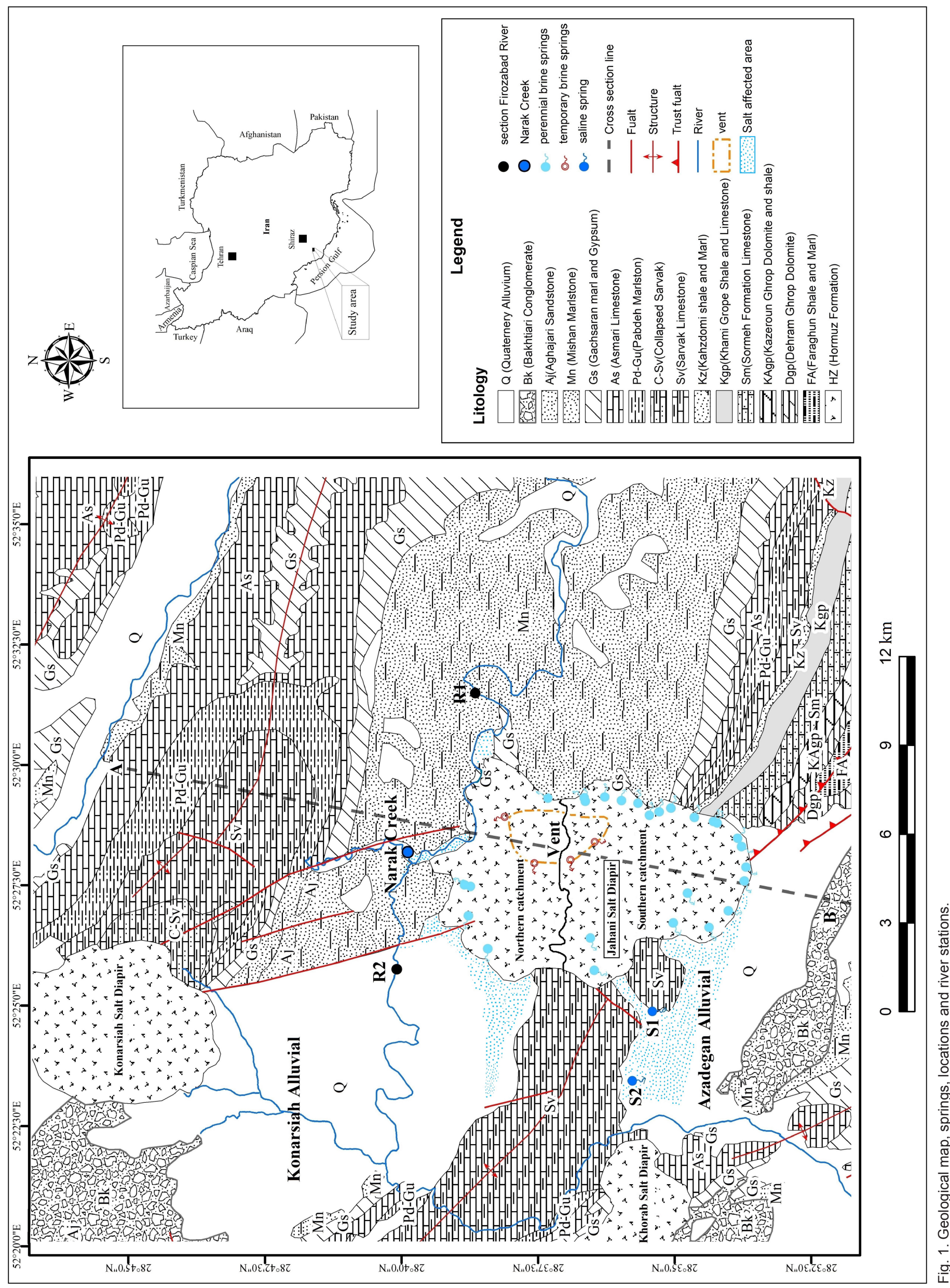


through thicknesses of 8 to $10 \mathrm{~km}$ of folded Phanerozoic sediments of the Zagros Mountains (Talbot, 1979).

The Hormuz salt, with an initial thickness of $1 \mathrm{~km}$ (Kent, 1979), was deposited on the rifted continental margins of the Arabian Plate (Stocklin, 1968). Boulder-sized inclusions of igneous, sedimentary, and metamorphic rocks are found inside this evaporite rock (Ahmadzade Heravi et al., 1990) broken sandstone, marl and carbonate are thrust repetitions of the Cambrian formations (Talbot et al., 2000).

The dextral strike-slip Mangarak Fault, with a north-south trend, has exposed five salt diapirs, namely the Sabuk, Murjan, Bachun, Konarsiah, and
Jahani Diapirs. The southern end of the Mangarak Fault changes to a thrust fault just to the south-east of the JDS, exposing Paleozoic- and Mesozoic-age formations (Talbot \& Alavi, 1996). The JSD is in direct contact with the Surmeh, Khami Group, Kazhdumi, Karstifid Sarvak, Pabdeh-Gurpi, Karstifid Asmari, Gachsaran, Mishan, and Bakhtiari Formations and with Quaternary alluvium. The groundwater of the JSD emerges from 26 permanent brine springs and 4 temporary brine springs (Fig. 1 and Fig. 3). The total discharge of permanent springs is $32.31 / \mathrm{s}$ (Table 1 ). The Firoozabad River flows from the east to west and it cuts through the northern outcrop of the JSD.

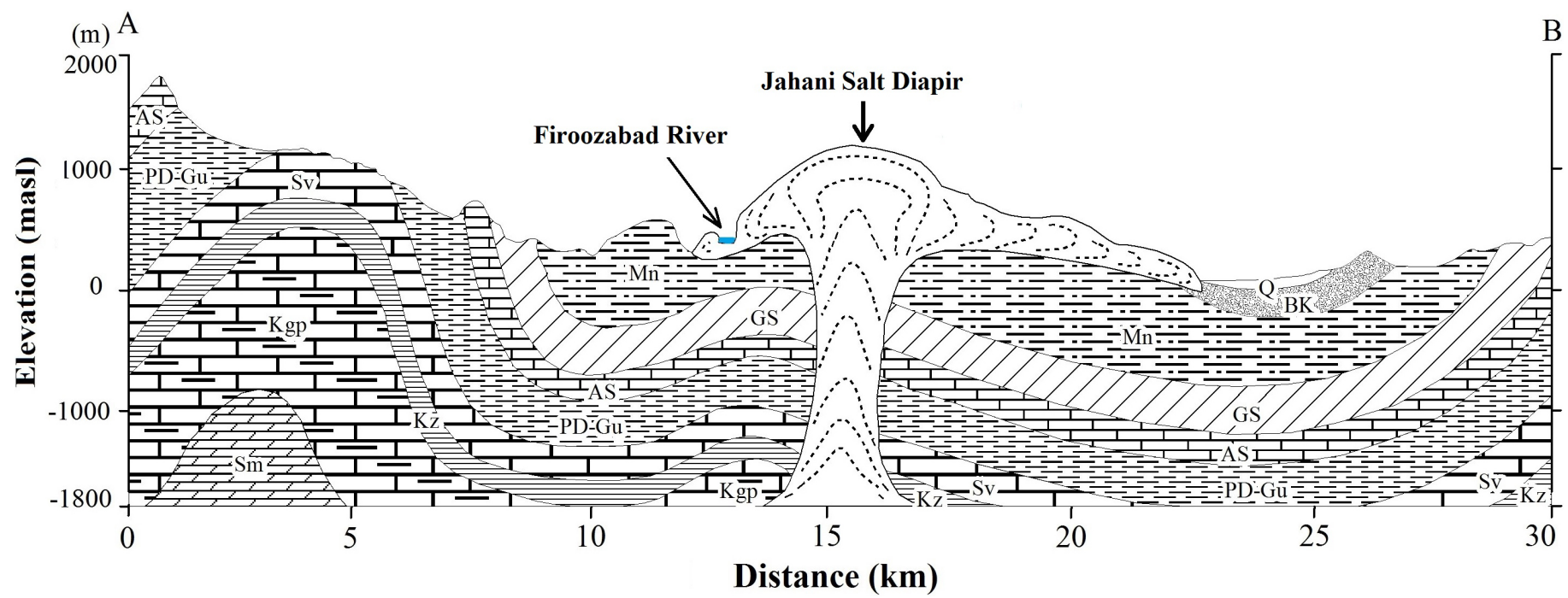

Fig. 2. Geological cross sections along AB (The AB cross section and legends are presented on Fig. 1) (After Talbot et al., 2000 and Edalatnia et al., 2012).

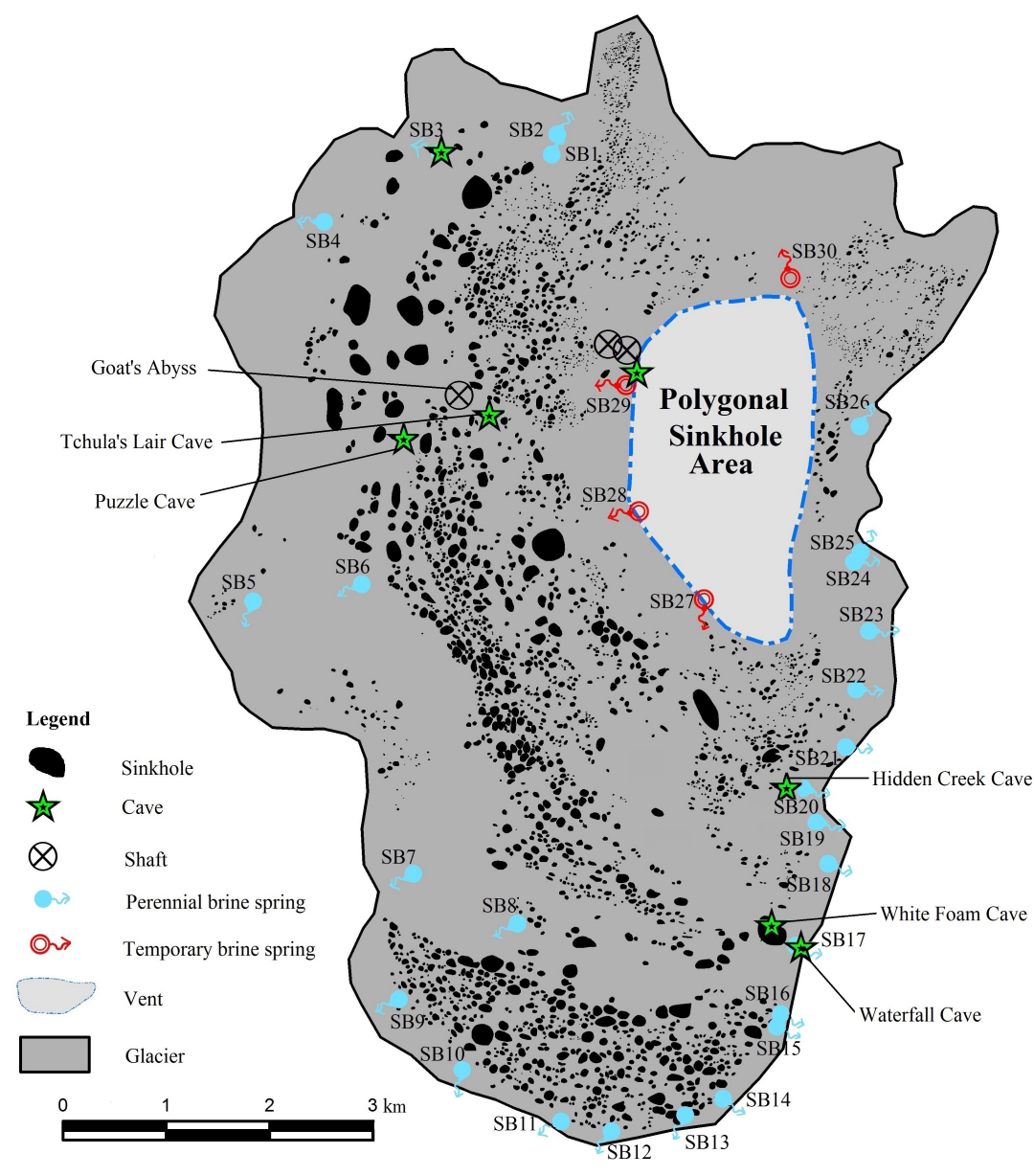

Fig. 3. Morphological map of the Jahani Salt Diapir.
The climate of the study area is semiarid, with a mean annual precipitation of $350 \mathrm{~mm}$. Precipitation occurs in late fall, winter, and early spring. The average daily temperature and Class A Pan evapotranspiration are $24.6^{\circ} \mathrm{C}$ and $2,835 \mathrm{~mm} \mathrm{a}^{-1}$, respectively.

\section{METHODS}

The discharges of 30 brine springs emerging from the JSD, plus two springs emerging from the Sarvak Formation, and the Narak Creek (Fig. 1 and Fig. 3) were measured using the volumetric method during the wet and dry seasons of 2013. The discharge of two hydrometric stations on the FR, upstream and downstream of the JSD (Fig. 1), were also measured monthly using a current meter (Valeport, model BFM 002). The major ion concentrations, electrical conductivity (EC), temperature (T), and total dissolved solids (TDS) of all the water resources were also measured. The major anions and cations were analyzed in the Hydrochemistry Laboratory of the Department of Earth Sciences, Shiraz University, Iran. Calcium and magnesium concentrations were measured by titration. Sodium and potassium concentrations 
Table 1. Slope, elevation of spring location, discharge of each brine spring, elevation difference between the top of the steep slopes and the location of the spring (EDSS), and the distance between the spring location with the boundary of the JSD (DSB).

\begin{tabular}{|c|c|c|c|c|c|}
\hline $\begin{array}{c}\text { Brine } \\
\text { Spring }\end{array}$ & $\begin{array}{c}\text { S1ope } \\
\left(\mathbf{}^{\mathbf{}}\right.\end{array}$ & $\begin{array}{c}\text { Elevation } \\
(\mathbf{m})\end{array}$ & $\begin{array}{c}\text { Discharge } \\
(\mathbf{1 / \mathbf { s }})\end{array}$ & $\begin{array}{c}\text { EDSS } \\
(\mathbf{m})\end{array}$ & $\begin{array}{c}\text { DSB } \\
(\mathbf{m})\end{array}$ \\
\hline SB27 & 28 & 1,294 & NM & 60 & 3,600 \\
\hline SB28 & 29 & 1,270 & NM & 100 & 3,800 \\
\hline SB29 & 35 & 1,280 & NM & 65 & 3,500 \\
\hline SB30 & 24 & 1,100 & NM & 70 & 1,150 \\
\hline SB6 & 22 & 920 & 1 & 80 & 1,400 \\
\hline SB8 & 23 & 835 & 2.2 & 40 & 1,300 \\
\hline SB4 & 11 & 836 & 2 & 24 & 320 \\
\hline SB5 & 13 & 747 & 1.9 & 26 & 500 \\
\hline SB1 & 26 & 905 & 2.7 & 70 & 380 \\
\hline SB2 & 20 & 890 & 1.8 & 50 & 170 \\
\hline SB3 & 20 & 875 & 3.5 & 40 & 200 \\
\hline SB10 & 26 & 648 & 1 & 55 & 100 \\
\hline SB11 & 29 & 670 & 0.6 & 45 & 100 \\
\hline SB12 & 35 & 675 & 0.3 & 55 & 75 \\
\hline SB13 & 30 & 700 & 0.8 & 100 & 150 \\
\hline SB14 & 29 & 700 & 0.8 & 105 & 60 \\
\hline SB15 & 29 & 735 & 1 & 90 & 100 \\
\hline SB16 & 30 & 740 & 1.1 & 128 & 120 \\
\hline SB17 & 30 & 777 & 2.4 & 77 & 100 \\
\hline SB18 & 29 & 830 & 1.1 & 100 & 160 \\
\hline SB19 & 26 & 832 & 1 & 88 & 100 \\
\hline SB20 & 23 & 897 & 1.2 & 128 & 150 \\
\hline SB21 & 26 & 910 & 1.2 & 40 & 130 \\
\hline SB22 & 20 & 980 & 1.2 & 40 & 300 \\
\hline SB23 & 17 & 980 & 0.7 & 90 & 200 \\
\hline SB24 & 17 & 1,090 & 0.9 & 110 & 270 \\
\hline SB25 & 17 & 1,090 & 0.8 & 110 & 200 \\
\hline SB26 & 22 & 1,165 & 1.1 & 105 & 200 \\
\hline & & & & & \\
\hline
\end{tabular}

were determined by flame photometry. Chloride and sulfate concentrations were measured by the Mohr and turbidity methods, respectively. Hydrogen carbonate was measured by titration with $\mathrm{HCl}$ using methylorange as indicator. The accuracies of the ion concentration measurements were determined by the balance method. The total dissolved solids (TDS) were determined by the evaporation method.

Two or more water sources with different salt concentrations are mixed in the study area. The unknown salt concentration $\left(c_{d}\right)$ was determined using the following mass balance equation:

$$
c_{d}=\frac{\sum_{i=1}^{n} c_{i} \times v_{i}}{\sum_{i=1}^{n} v_{i}}
$$

where $c_{i}$ is average salt concentration $(\mathrm{mg} / \mathrm{l}), \mathrm{v}_{\mathrm{i}}$ is the volume of water $\left(\mathrm{m}^{3}\right)$, and $\mathrm{n}$ is the number indicative of the water resource(s). The dissolved halite mass (DHM) in tons, transported by the water for the period under consideration is calculated using the following equation:

$$
D H M=10^{-6}(\mathrm{~V} \times H C)
$$

where $V$ is the total volume of water $\left(\mathrm{m}^{3}\right)$ and $H C$ is the halite concentration $(\mathrm{mg} / \mathrm{l})$.

\section{RESULTS AND DISCUSSION}

\section{Morphology}

The JSD has an area of $54 \mathrm{~km}^{2}$ and a semi-elliptical outline on the map (Fig. 4). The maximum length and width of the diapir are 10.4 and $6.5 \mathrm{~km}$, respectively. The minimum, average, and maximum elevations of the JSD are about 575, 900, and 1,476 $\mathrm{m}$ as1 ( $\mathrm{m}$ above sea level), respectively. The JSD divides into northern and southern sub-catchment areas (Fig. 1); the runoff of these sub-catchment areas joins the FR and reaches the Azadegan Alluvium, respectively.

The most significant karst features of the JSD are: rillenkarren, shafts, blind valleys, caves, brine springs, and sinkholes. The morphological map shows the sinkholes with diameters of more than 10 meters on the glacier, as well as the brine springs, known shafts and caves, and polygonal sinkholes with diameters mainly less than $10 \mathrm{~m}$ in the vent area (Fig. 3). The vent is the orifice from which salt rises and emerges on the surface. A summit dome above the vent is located near the northeast boundary, at an average elevation of $1,410 \mathrm{~m}$ asl. It is $250 \mathrm{~m}$ higher than the surrounding glacier (Fig. 5). The average width and length of the vent are 1.8 and $2.6 \mathrm{~km}$, respectively. The vent is dotted by polygonal sinkholes, partly covered by cap soil, sparse plants and/or salt exposures on the steeper slopes of the sinkholes (Fig. 6). The most active part of the vent, consists of $10 \mathrm{~m}$ blocks of crushed salt rocks with few igneous, metamorphic and sedimentary inclusions (Fig. 7). The vent is connected to the surrounding glacier by slopes steeper

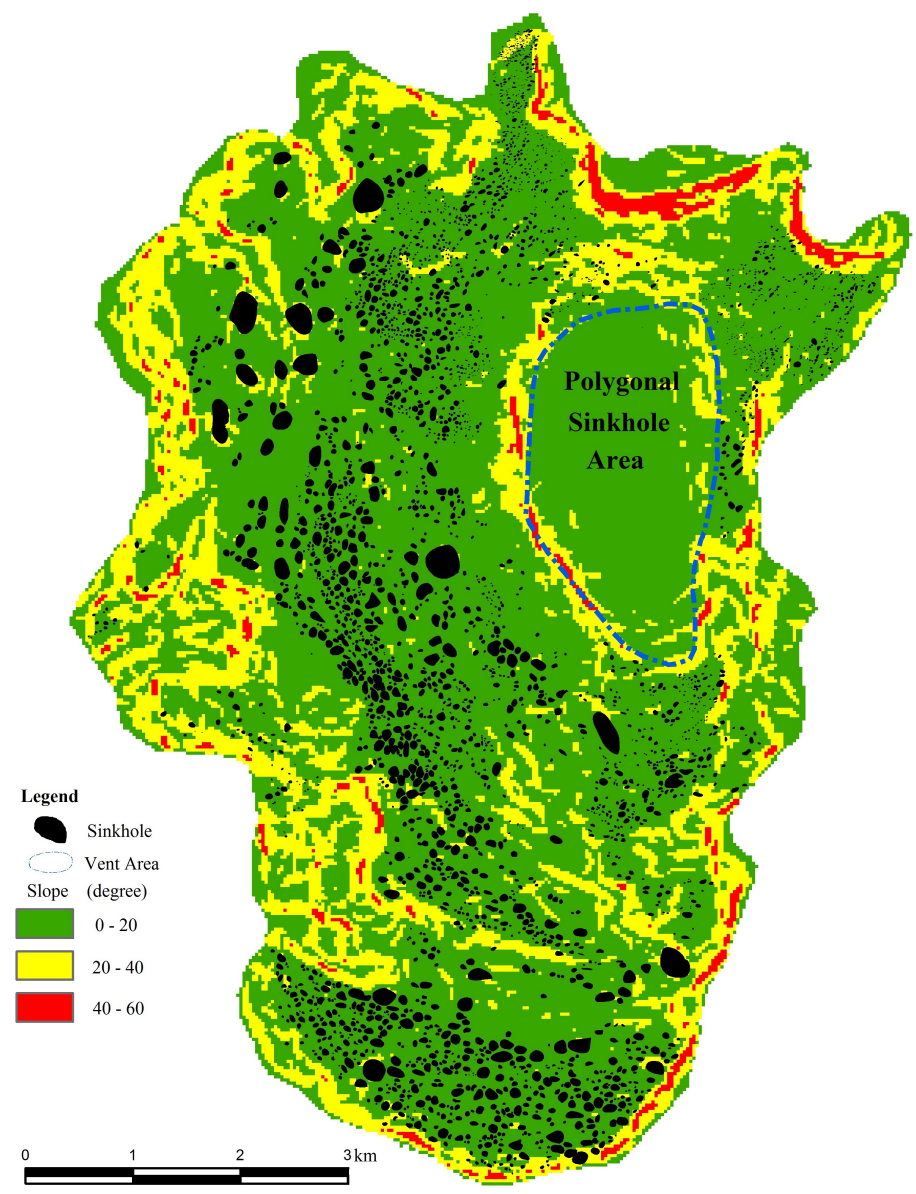

Fig. 4. Distribution map of sinkholes having diameters larger than $10 \mathrm{~m}$ in the glacier area. 

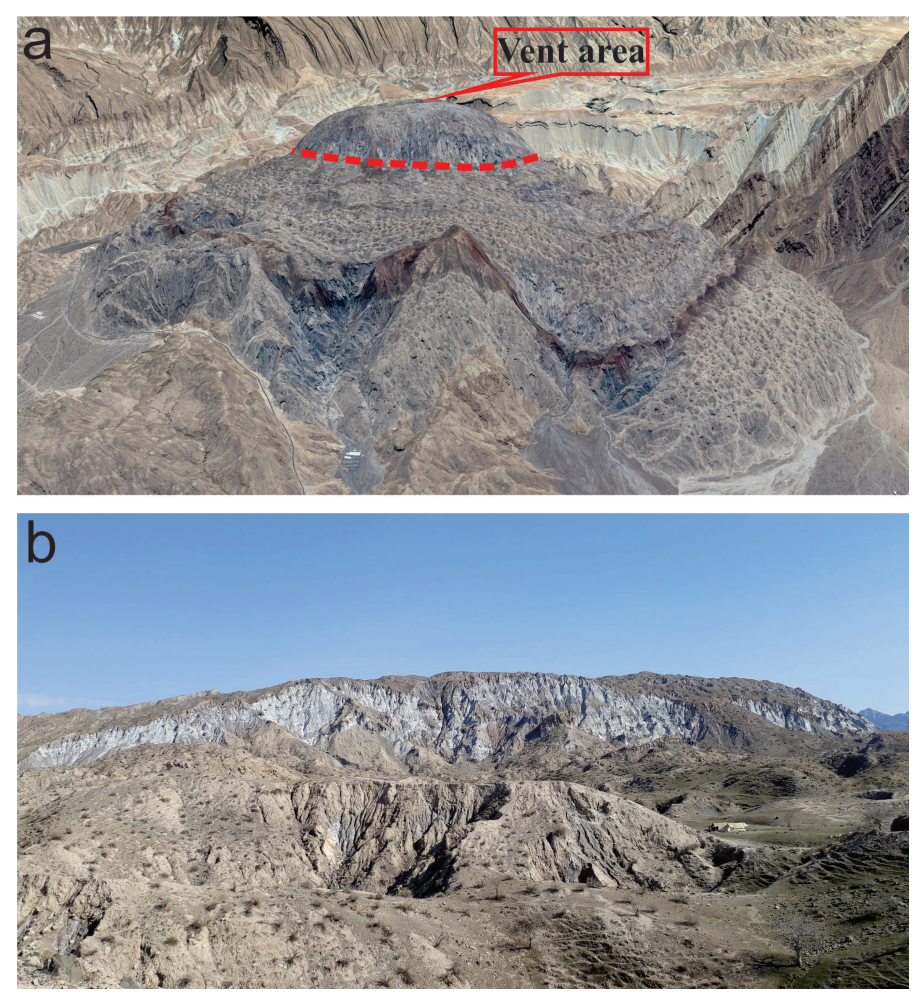

Fig. 5. a) Google Earth image the vent and adjacent lower glacier area; b) Exposed salt rocks on a steep slope between the vent and glacier.

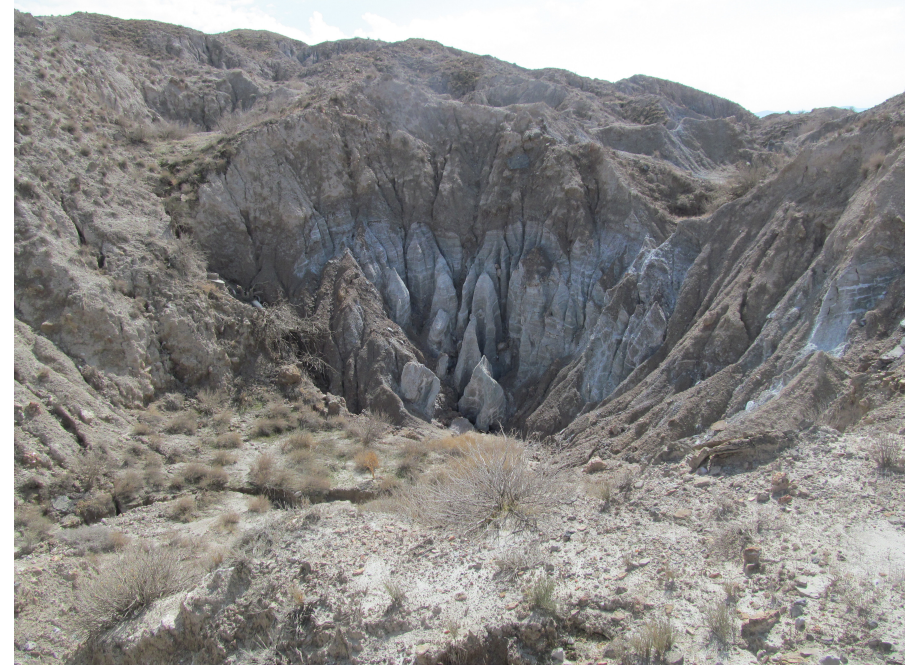

Fig. 6. Sinkhole with residuum soil and plant coverage on the top, and exposed salt rocks on the steep slopes.

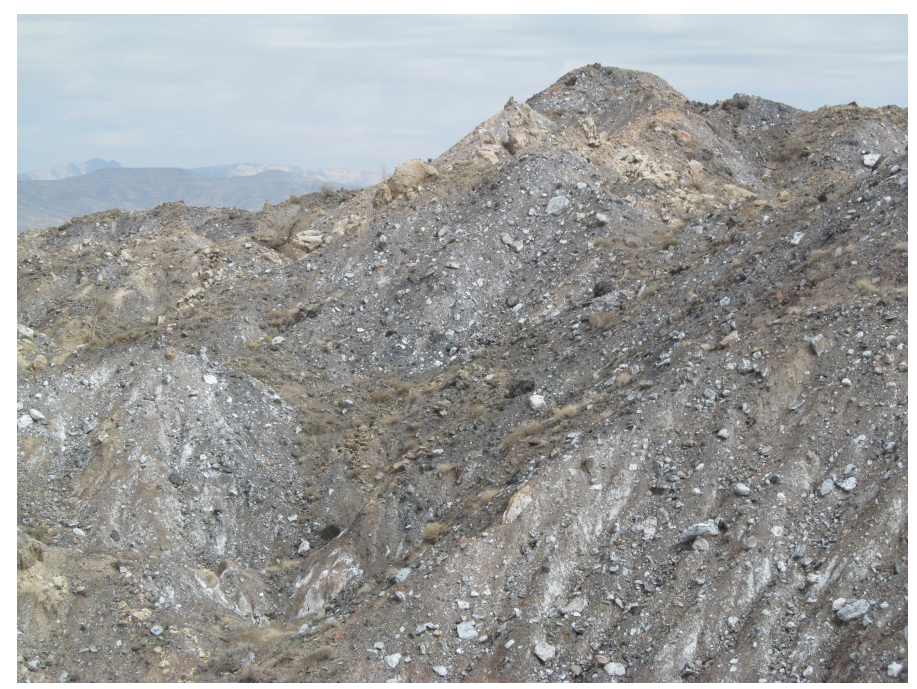

Fig. 7. A Sinkhole on the active vent area. than $30^{\circ}$ and elevation differences of about $250 \mathrm{~m}$. The main reasons for such high elevation differences may be the rapid rate of salt influx due to current $\mathrm{S}-\mathrm{N}$ shortening across the Zagros Mountains tectonic activities. Talbot et al. (2000) precisely surveyed 43 ground markers 3 times in a 4.5-year interval and modelled the results in terms of a salt flowing with a viscosity near $10^{16}$ to ${ }^{17} \mathrm{~Pa} \mathrm{~s}^{-1}$ rising up the diapir at 2-3 $\mathrm{m} / \mathrm{a}$ and spreading downslope at $4-6 \mathrm{~m} / \mathrm{a}$ high on the summit dome slowing to $<0.5 \mathrm{~m} / \mathrm{a}$ about $6 \mathrm{~km}$ downstream to the south of the namakier for about $55 \pm 20 \mathrm{ka}$. These measurements resulted in maps of salt displacement suggesting that Jahani is currently the fastest extruding subaerial salt on planet Earth.

The glacier, with an area of $49.5 \mathrm{~km}^{2}$, has spread downslope to the south and east of the vent, because the high topography of the adjacent geological formations prevented glacier movement in other directions and large volumes of the JSD salt are dissolved by the FR. Most of the glacier is covered by cap soil except on slopes greater than $35^{\circ}$ where the salt rock is exposed due to the fact that covers of cap soil slump downslope. The sinkholes are covered by residual soil, except on the steepest slopes. The glacier cap soil is covered by pastures and trees. Parts of the glacier in the north of the JSD move toward the FR and are dissolved by the river water.

The total number of sinkholes with diameters greater than $10 \mathrm{~m}$ on the glacier area was 3,590 with a total area of $5.2 \mathrm{~km}^{2}$. The percentages of sinkhole area and sinkhole density are, $10.5 \%$ and $73 \mathrm{~N} /$ $\mathrm{km}^{2}$, respectively. The largest sinkhole has a length and area of $459 \mathrm{~m}$ and $84518 \mathrm{~m}^{2}$, respectively. The sinkholes on the glacier are mainly developed by capsoil and/or soil cover collapse. The area of exposed salt rocks is $11 \%$ of the total JSD area (Fig. 8). The salt-affected area outside of the JSD but without any karst features has an area of $16 \mathrm{~km}^{2}$ (Fig. 1).

\section{Cave characteristics}

Vertical longitudinal profiles suggest two groups of caves on the JSD (located on Fig. 2 in Bruthans et al., 2017): (i) sub-horizontal or inclined stream passages, with some vertical steps, and (ii) vertical shafts (Fig. 9 illustrates examples of cave maps). The first group of caves is typically situated at the end of blind and semi-blind valleys and larger elongated sinkholes with temporary streams collected on a thick residuum. Nineteen sub-horizontal caves were visited and ten of them were also mapped (Bruthans et al., 2004). Most of the caves located inside the JSD are probably inlet caves terminated either by impassably narrow spaces blocked by deposited sediments or by collapsed blocks of rock salt in large collapse halls (e.g., in the Tchula's Lair Cave, Filippi et al., 2010). Small parts of some caves, usually parts of larger collapsed systems, or located near the diapir margin, are outlet caves, passable through or accessible via their resurgences. These are situated around the eastern, southern and western part of the diapir. So far, only one cave longer than one kilometer is known $(1,262 \mathrm{~m}$, depth $84 \mathrm{~m})-$ the White Foam Cave (Filippi et al., 2006). This cave is a part of a larger system (see Fig. 3 in Bruthans et 


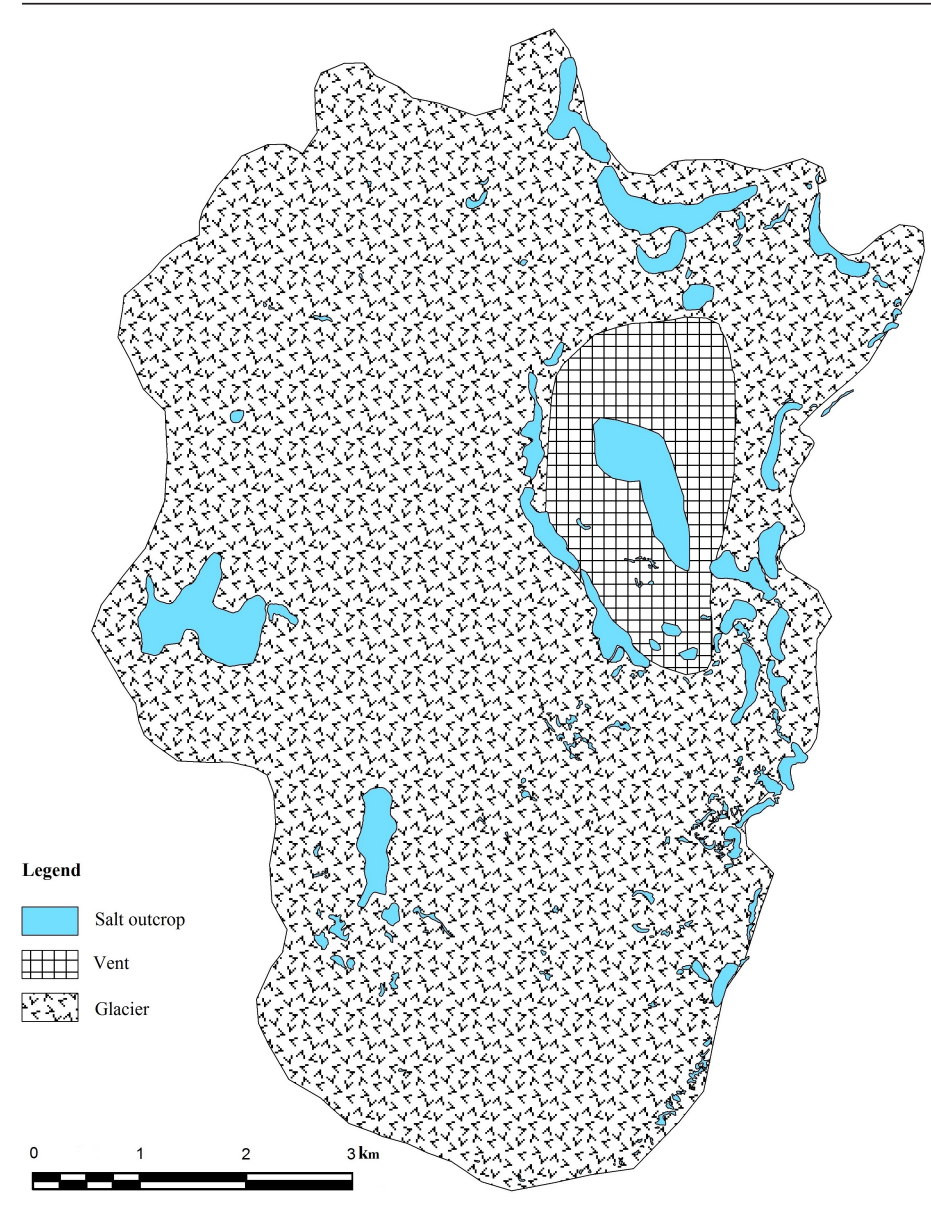

Fig. 8. Salt rock exposure on the Jahani Salt Diapir.

al., 2004) and consists of two tributary branches that connect downstream to a single passage. Halls with a collapsed roof alternate with meandering segments of cave passage. Some of the caves are richly decorated by various halite speleothems.

Caves and cave segments located precisely on a margin of the JSD have relatively steep slope and/or up to $15 \mathrm{~m}$ high vertical steps. Both Hidden Creek Cave (length 478 m, depth 88 m; Fig. 9) and Waterfall Cave with a $15 \mathrm{~m}$ high waterfall (length $424 \mathrm{~m}$, depth $79 \mathrm{~m}$ ) occur on the southeastern margin of the JSD and are the most interesting examples. The flow rate in these marginal caves is usually several liters per second or less; however, during heavy rains it rises significantly (Bruthans et al., 2017). Splashes and aerosol brines precipitate fascinating halite speleothems around the waterfalls (Filippi et al., 2011a).

Shafts and shaft-related caves are typical for short circular valleys and collapse sinkholes, commonly without a large water supply. An important factor for shaft development seems to be sub-surficial corrosion of the shaft walls by a water film, especially in the early stages of their development. The largest and deepest explored shaft - the Goat's Abyss -is ca. $70 \mathrm{~m}$ deep and is in the western part of the JSD (Filippi et al., 2011b, 2013). The bottom of vertical shafts in the JSD typically resembles a circular funnel-shaped sinkhole. Sinkhole walls and several tens of meters high upper portion of most shafts consist of partly consolidated cap soil containing large blocks of salt rock (Fig. 9). Shafts in rock salt usually have oval horizontal crosscuts and bottle-like vertical profiles. After a horizontal passage usually up to $150 \mathrm{~m}$ long, the caves terminate in impassable riverbed sediment and debris.

Except for most sinkholes and the types of caves mentioned above, the Puzzle Blind valley represents a specific type of blind valley with a complex genesis (Filippi et al., 2013). The branched labyrinth-type canyon with walls up to $13 \mathrm{~m}$ high, but only $0.5-1.5 \mathrm{~m}$ wide, is situated on a flat bottom of the terminal part of a valley with an area of $100 \times 200$ m. Fine deposits that settled there during numerous floods in the past, when the swallow hole at the bottom of the valley was inactive, floor this valley. Later the swallow hole was re-activated and narrow canyons were incised by headward erosion of sedimentary fill during heavy rains. Recently the streams enter the swallow hole from several directions by several canyon branches joining together before draining into the Puzzle Cave. This cave starts with a $15 \mathrm{~m}$ deep vertical step followed by a gradually decreasing underground space ca. $130 \mathrm{~m}$ long.

Caves on the JSD are in general steeper than those on Persian Gulf coastal diapirs, e.g. Hormoz and Namakdan (see Bruthans et al., 2010 for cave characteristics there). Vertical steps with waterfalls and rapid flow are common in caves on the JSD. Caves with open outlets have typically high but narrow meandering passages on the JSD, which has been unseen on coastal diapirs, where low and very wide passages prevail. Inlet caves on the JSD however end up with low and wide passages due to fast aggradation of trapped sediments. No effect of rapid salt movement was observed in caves on the JSD. Cave passages are not cut by faults nor terminated due to moving salt. Evolution of cave passages is clearly faster than movements due to halokinesis. Bedding planes (foliation) control most of the caves visited on Iranian Salt Karst. On the JSD most of the caves are meandering passages with roof covered by salt sinters, so original protoconduits are not accessible for study.

\section{Brine springs}

Twenty-six perennial and four temporary brine springs emerge from the JSD, and three of them $\mathrm{SB}_{3}$, $\mathrm{SB}_{17}$, and $\mathrm{SB}_{20}$ emerge from outlet caves (Fig. 4). The average, minimum, and maximum discharge of the brine springs are, respectively, $1.4,0.2$, and $2.91 / \mathrm{s}$ during the dry season, and $1.8,0.3$, and $41 / \mathrm{s}$ during the wet season (Table 1). The average catchment area of these brine springs is about $1.8 \mathrm{~km}^{2}$. During the dry season, most brine springs infiltrate into the glacier's cap soil in a short distance after emergence. The major ion concentrations of the brine springs are presented on Fig. 10. The minimum, maximum and average TDS values are 310, 324, and $317 \mathrm{~g} / 1$, respectively. The average percentage of sodium chloride is $98 \%$. All the brine springs are supersaturated with respect to halite, calcite, dolomite and gypsum as determined by PHREEQC model (Parkhurst \& Appelo, 1999), because the cap soils are composed of gypsum, anhydrite, calcite and dolomite (Bruthans et al., 2008).

The elevation, slope and discharge of each brine spring, and the shortest distance between them and the boundary of the JSD (DSB) are listed in Table 1. 


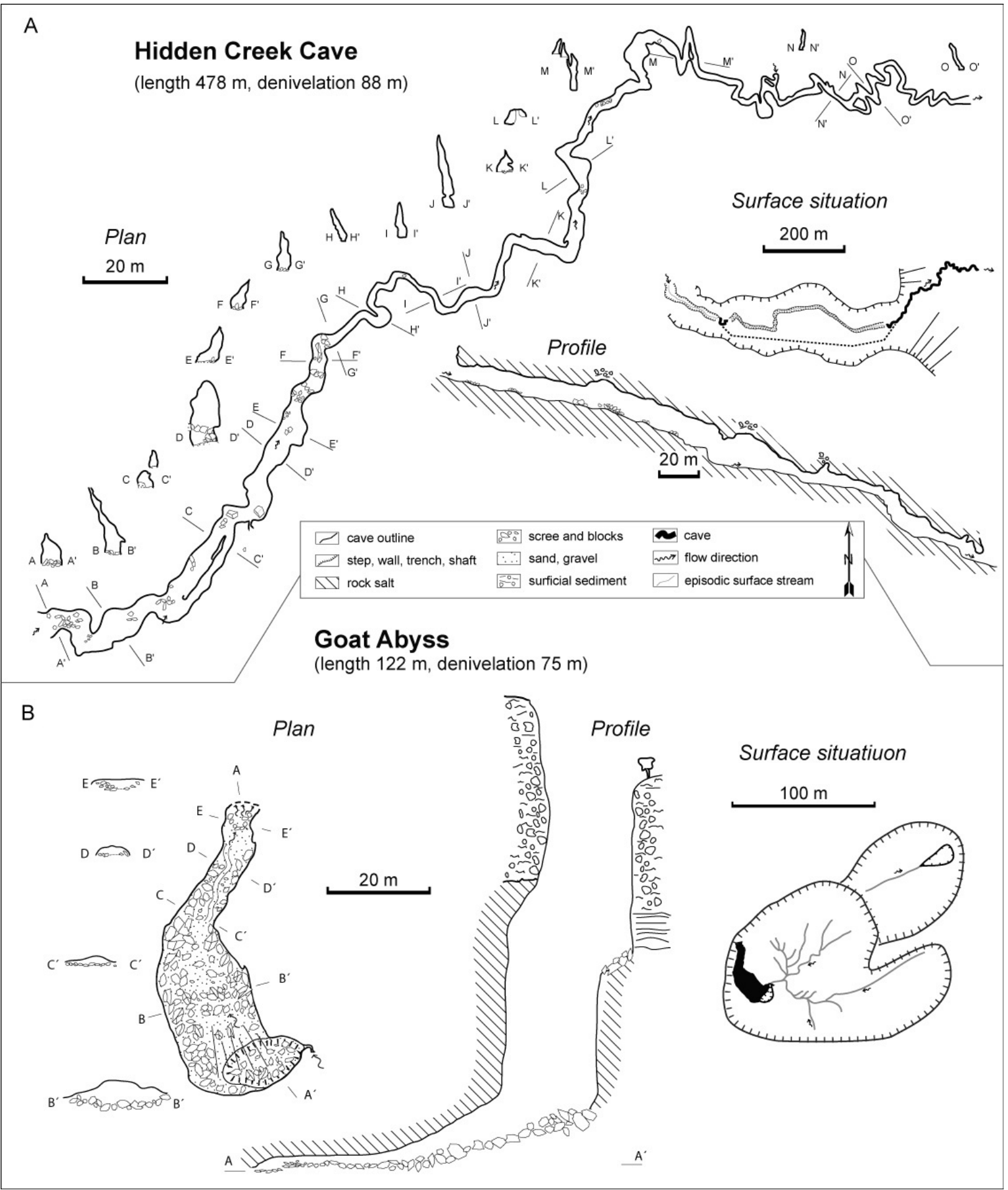

Fig. 9. Examples of two different types of caves on the JSD: A) The Hidden Creek Cave as an inclined stream passage type and B) Goat Abyss as a vertical shaft type. (Mapped by the NAMAK team members and drawn by M. Kolcava, O. Jäger, and M. Filippi).

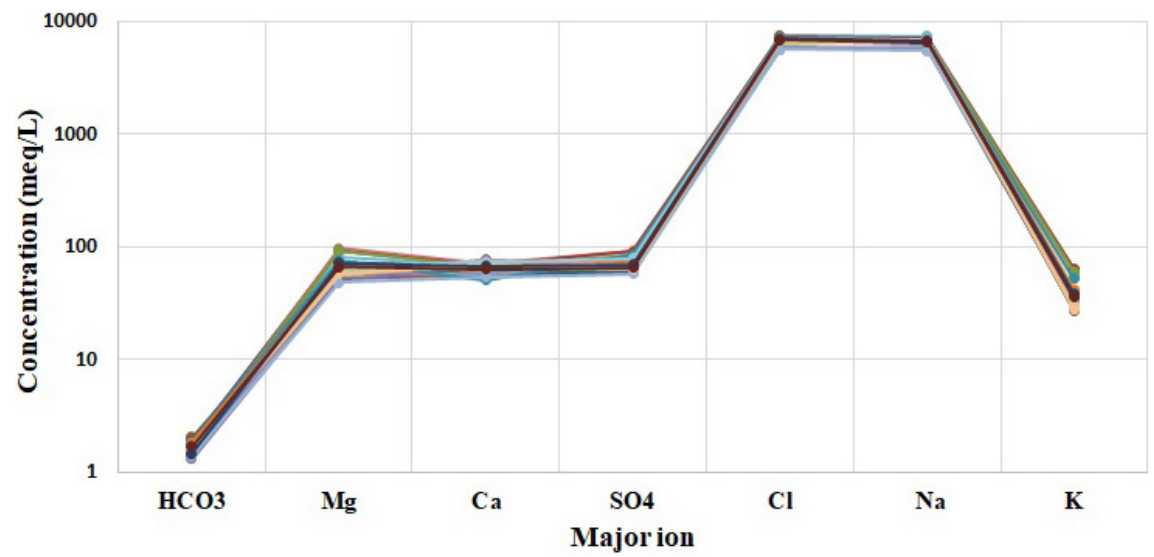

Fig. 10. Major ion concentrations of the brine springs. 
The $\mathrm{SB}_{27}, \mathrm{SB}_{28}, \mathrm{SB}_{29}$, and $\mathrm{SB}_{30}$ temporary springs are located on steep slopes around the vent, at elevations ranging from 1,100 to $1,290 \mathrm{~m}$ asl Other than $\mathrm{SB}_{4}$ and $\mathrm{SB}_{5}$ that drain from the gentle slopes, the remaining springs emerge through glacial salt exposed in steep slopes above the local base of erosion. None of the springs emerge from the gently sloping glacier areas because the water table is below the ground surface.

The main reason that springs emerge from steep slopes above the local base of erosions is that salt deeper than about 40 to $60 \mathrm{~m}$ is impermeable with negligible porosities because it is actively flowing (Frumkin, 2000; Zarei \& Raeisi, 2010b). Flowing salt is incapable of developing cave systems because the groundwater becomes saturated with respect to halite (Frumkin, 2000) as it drains through the fractures in the outer broken and weathered layer or skin that can reach thicknesses of tens of meters (Talbot et al., 2009). The high viscosity of brine causes its threshold aperture to be at least several centimeters before the turbulent flow that aids salt dissolution occurs (Frumkin, 1994). The joint apertures may be small enough to hinder dissolution and, in effect, prevent cave development even in the surficial broken salt. A schematic model of groundwater flow direction and spring locations is presented in Fig. 11. The lack of karst development and flow at great depths in the JSD are justified by the following reasons:

1) The differences in elevation between the top of the steep slopes and the brine springs (EDSS) range from 40 to $128 \mathrm{~m}$ (Table 1 ) and justifies the idea that the springs emerge above the local base of erosion.

2) No springs are occurring along the contact of the JSD salt with adjacent geological formations, and the elevation differences of springs along the JSD boundary range from 15 to $60 \mathrm{~m}$, indicating the lack of karst development in the salt beneath each spring.

There is no groundwater flow from the JSD toward the karst aquifers in the Asmari, Sarvak, Khami
Group, nor Surmeh to the south-east (Fig. 1). This is demonstrated by the ECs of the water resources emerging from these aquifers at great distances from the JSD, which are less than $1200 \mu \mathrm{mho} / \mathrm{cm}$ (Yari, 2017). Two springs $S_{1}$ and $S_{2}$ emerge from the southwest karstic Sarvak Aquifer with total discharge of about $15 \mathrm{l} / \mathrm{s}$ and ECs of about $40000 \mu \mathrm{mho} / \mathrm{cm}$. The source of high electrical conductivity of these two springs is intrusion of the JSD brine into this aquifer (Table 2, Fig. 1). Using Eq. 2, the share of the JSD brine is about $21 / \mathrm{s}$.

The water budget of the JSD is estimated during hydrological year 2013-2014 by the following equation:

$$
V=P \times I \times A
$$

where $V$ is the annual volume of precipitation recharging the JSD, $P$ is the annual precipitation onto the JSD $(0.300 \mathrm{~m}), A$ is the JSD outcrop area $\left(54 \mathrm{~km}^{2}\right)$, and $I$ is the recharge coefficient. The recharge coefficient is estimated to be $9 \%$, based on hydrogeological studies of the smaller Konarsiah Salt Diapir (Fig. 1) 10 $\mathrm{km}$ north of the JSD (Zarei et al., 2011). The average annual recharge is therefore about $1.46 \mathrm{MCM} / \mathrm{a}$. The JSD groundwater emerges from 30 brine springs $(361 / \mathrm{s})$, as well as from springs $\mathrm{S}_{1}$ and $\mathrm{S}_{2}(2 \mathrm{1} / \mathrm{s})$. The rest of the recharge water $(0.32 \mathrm{MCM} / \mathrm{a})$ seeps into the FR and flows into the adjacent Azadegan Alluvial Aquifer (Fig. 1). The runoff from the southern catchment area of the JSD enters the adjacent Azadegan Alluvium that consists mainly of evaporites and secondary salts deposited on the ground surface (in the salt-affected area). The runoff from the northern catchment area joins the $\mathrm{FR}$, especially the brines from springs $\mathrm{SB}_{1}$, $\mathrm{SB}_{2}$ and $\mathrm{SB}_{3}$ during the wet season.

The TDS and discharges of the FR at the $R_{1}$ and $R_{2}$ stations (Fig. 1), before and after direct contact with the JSD, and DHM at the $\mathrm{R}_{2}$ station are presented in Fig. 12. The minimum, maximum and average TDS are, respectively, 577, 923, and $762 \mathrm{mg} / 1$ at station $\mathrm{R}_{1}$ and $6,200,23,380$, and $13,451 \mathrm{mg} / 1$ at station $R_{2}$. The increases of the average TDS and discharge

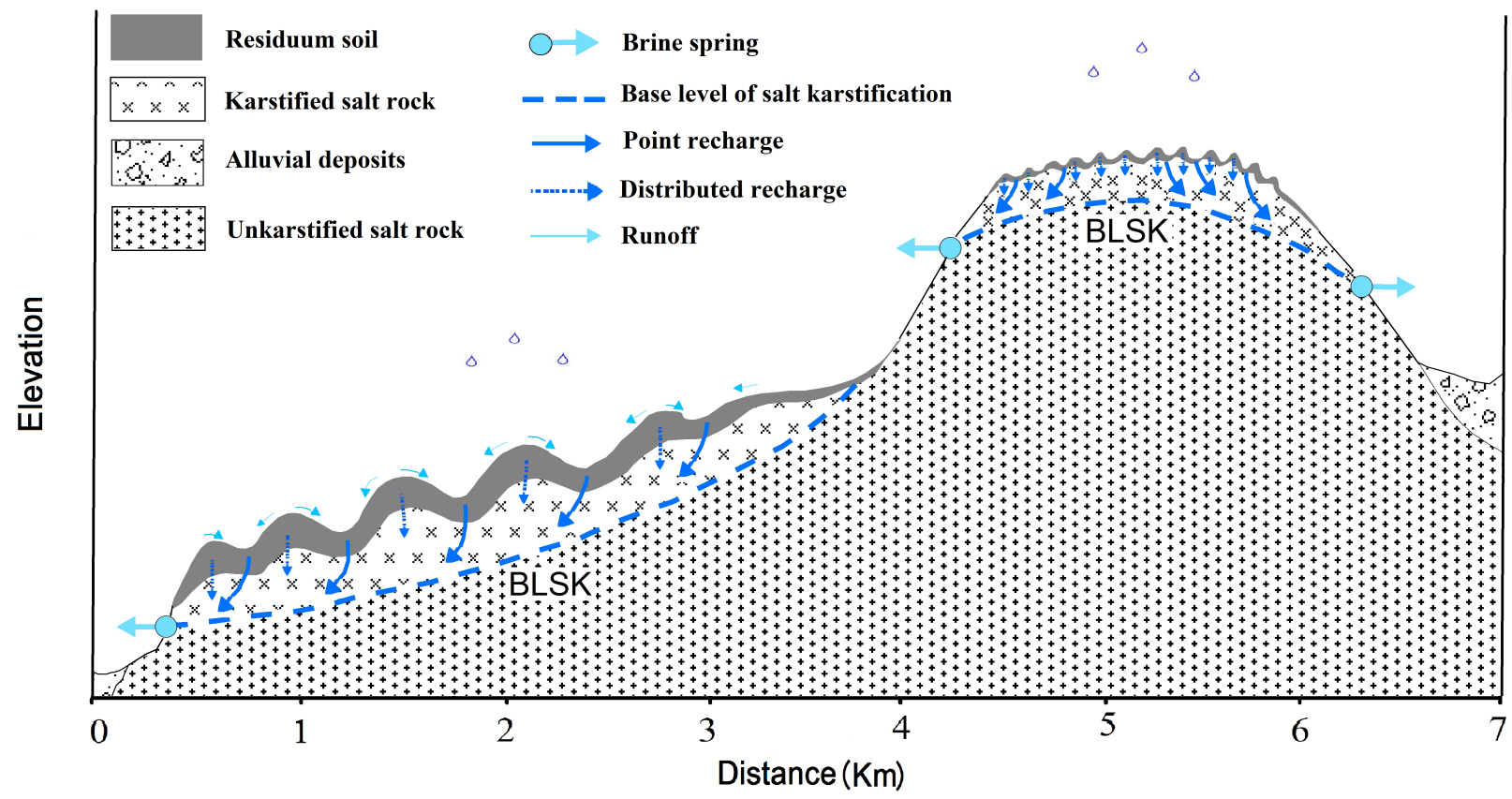

Fig. 11. Schematic model of flow direction in the Jahani Salt Diapir. 
between the two stations are $12,690 \mathrm{mg} / 1$ and $37 \mathrm{l} / \mathrm{s}$, respectively (Table 3 ). The TDS at the $R_{2}$ station is due to mixing from various water sources. Most dissolution of salt is by direct contact with the FR together with discharges from the brine springs $\mathrm{SB}_{1}, \mathrm{SB}_{2}$, and $\mathrm{SB}_{3}$, runoff from the northern catchment area, and the Narak Creek. At low discharges, the TDS increases (Fig. 12) because the discharge and TDS of the brine springs are almost constant during both wet and dry periods. However, the share of the brine springs on the TDS is higher during the dry season. The DHM at the $\mathrm{R}_{2}$ station decreases during the dry period due to the reduced discharge of the FR (Fig. 12).

The volume of water joining the FR during the study period and their average halite concentrations are listed in Table 4. The JDS halite carried downstream dissolved in the FR is calculated using Eq. 1. The average halite concentration increased from $100 \mathrm{mg} / 1$ at Station $\mathrm{R}_{1}$ to $12,070 \mathrm{mg} / \mathrm{l}$ at Station $\mathrm{R}_{2}$, and the total dissolved halite mass increased from 1,680 tons at Station $R_{1}$ to 213,150 tons at Station $R_{2}$ during the study period. About $75 \%$ of the increases in $\mathrm{NaCl}$ concentration at Station $\mathrm{R}_{2}$ was due to direct dissolution of the JSD by FR. The dissolution of the JSD by the FR is a permanent process because of: a) rapid ductile flow of the active glacier into the river gorge, b) the short distance between the JSD vent and the FR, c) markers flowed down steep slopes towards the river cliffs at $1.4 \mathrm{~m} /$ month (Talbot et al., 2000) before breaking up and collapsing in huge rock falls that can dam the river for weeks in the rainy season.

Table 2. Facies, major ion concentrations, TDS, EC, $\mathrm{pH}$, temperature and discharge of the Sarvak Aquifer springs $\left(\mathrm{s}_{1}\right.$ and $\left.\mathrm{s}_{2}\right)$ and the Narak creek $\left(\mathrm{Rs}_{1}\right)$ in the dry and wet seasons.

\begin{tabular}{|c|c|c|c|c|c|c|c|c|c|c|c|c|c|c|}
\hline \multirow{2}{*}{$\begin{array}{c}\text { Sampling } \\
\text { time }\end{array}$} & \multirow{2}{*}{$\begin{array}{c}\text { Sampling } \\
\text { points }\end{array}$} & \multirow{2}{*}{ Facies } & $\mathbf{C a}$ & Mg & $\mathbf{N a}$ & $\mathbf{K}$ & $\mathrm{HCO}_{3}$ & $\mathrm{SO}_{4}$ & $\mathbf{C l}$ & \multirow{2}{*}{$\begin{array}{l}\text { TDS } \\
\text { (g/1) }\end{array}$} & \multirow{2}{*}{$\begin{array}{c}\text { EC } \\
(\mathrm{ms} / \mathrm{cm})\end{array}$} & \multirow{2}{*}{ pH } & \multirow{2}{*}{$\begin{array}{c}\mathbf{T} \\
\left({ }^{\circ} \mathrm{C}\right)\end{array}$} & \multirow{2}{*}{$\begin{array}{c}\text { Discharge } \\
(1 / \mathrm{s})\end{array}$} \\
\hline & & & \multicolumn{7}{|c|}{ (meq/1) } & & & & & \\
\hline \multirow{3}{*}{$\begin{array}{c}\text { Dry } \\
\text { Season }\end{array}$} & $\mathrm{S}_{1}$ & $\mathrm{Na}-\mathrm{Cl}$ & 29.8 & 23.5 & 659.2 & 4.0 & 4.5 & 45.6 & 635.7 & 32.56 & 43,684 & 7.8 & 32 & 0.5 \\
\hline & $\mathrm{S}_{2}$ & $\mathrm{Na}-\mathrm{Cl}$ & 32.7 & 21.9 & 586.8 & 3.6 & 4.7 & 48.0 & 645.7 & 36.19 & 45,631 & 7.8 & 31 & 8 \\
\hline & $\mathrm{R}_{\mathrm{S} 1}$ & $\mathrm{Na}-\mathrm{Cl}$ & 6.2 & 4.6 & 8.1 & 0.1 & 4.8 & 5.0 & 7.9 & 0.82 & 1,340 & 8.1 & 27 & 10 \\
\hline \multirow{3}{*}{$\begin{array}{c}\text { Wet } \\
\text { Season }\end{array}$} & $\mathrm{S}_{1}$ & $\mathrm{Na}-\mathrm{Cl}$ & 27.5 & 21.4 & 646.8 & 3.1 & 4.4 & 44.1 & 611.3 & 31.77 & 42,100 & 7.7 & 30 & 1 \\
\hline & $\mathrm{S}_{2}$ & $\mathrm{Na}-\mathrm{Cl}$ & 30.7 & 19.9 & 577.7 & 3.4 & 4.3 & 42.2 & 608.2 & 35.51 & 44,300 & 7.6 & 28 & 15 \\
\hline & $\mathrm{R}_{\mathrm{S} 1}$ & $\mathrm{Na}-\mathrm{Cl}$ & 5.0 & 4.4 & 7.0 & 0.1 & 5.0 & 3.3 & 7.3 & 0.76 & 1,200 & 8.2 & 18 & 40 \\
\hline
\end{tabular}

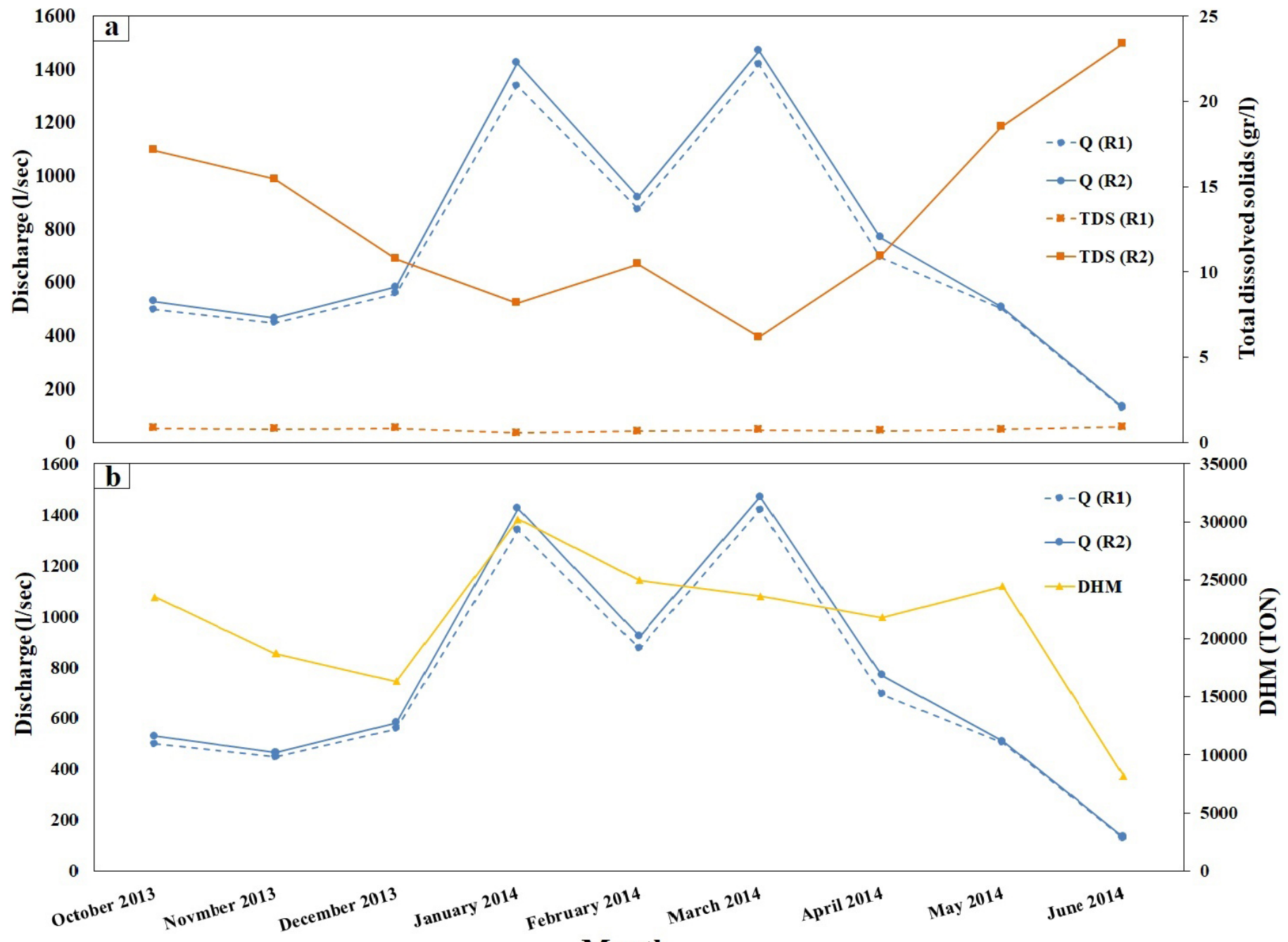

\section{Month}

Fig. 12. The monthly time variation of Firoozabad River: a) TDS and discharge at Stations $R_{1}$ and $R_{2}$; b) DHM (dissolved halite mass) at Station $R_{2}$ and discharge at Stations $\mathrm{R}_{1}$ and $\mathrm{R}_{2}$. 
Table 3. Facies, major ion concentrations, TDS, EC, $\mathrm{pH}$, temperature and discharge of the Firoozabad River at stations $\mathrm{R}_{1}$ and $\mathrm{R}_{2}$.

\begin{tabular}{|c|c|c|c|c|c|c|c|c|c|c|c|c|c|c|}
\hline \multirow{2}{*}{$\underset{\text { time }}{\text { Sampling }}$} & \multirow{2}{*}{$\begin{array}{c}\text { Sampling } \\
\text { points }\end{array}$} & \multirow{2}{*}{ Facies } & $\mathbf{C a}$ & Mg & $\mathbf{N a}$ & $\mathbf{K}$ & $\mathrm{HCO}_{3}$ & $\mathrm{SO}_{4}$ & $\mathbf{C l}$ & \multirow{2}{*}{$\begin{array}{l}\text { TDS } \\
(\mathrm{g} / 1)\end{array}$} & \multirow{2}{*}{$\begin{array}{c}\text { EC } \\
(\mathbf{m s} / \mathbf{c m})\end{array}$} & \multirow{2}{*}{ pH } & \multirow{2}{*}{$\begin{array}{c}\mathrm{T} \\
\left({ }^{\circ} \mathrm{C}\right)\end{array}$} & \multirow{2}{*}{$\begin{array}{c}\text { Discharge } \\
(1 / \mathbf{s})\end{array}$} \\
\hline & & & \multicolumn{7}{|c|}{ (meq/1) } & & & & & \\
\hline \multirow{2}{*}{$\begin{array}{c}\text { October } \\
2013\end{array}$} & $\mathrm{R}_{1}$ & $\mathrm{Ca}-\mathrm{HCO}_{3}$ & 8.5 & 0.3 & 3.1 & 0.1 & 4.9 & 4.5 & 2.3 & 0.848 & 1,020 & 7.7 & 25 & 500 \\
\hline & $\mathrm{R}_{2}$ & $\mathrm{Na}-\mathrm{Cl}$ & 14.1 & 8.6 & 261.2 & 1.5 & 4.1 & 22.3 & 268.9 & 17.14 & 21,838 & 7.7 & 25 & 530 \\
\hline \multirow{2}{*}{$\begin{array}{c}\text { November } \\
2013\end{array}$} & $\mathrm{R}_{1}$ & $\mathrm{Ca}-\mathrm{SO}_{4}$ & 7.0 & 1.0 & 2.5 & 0.1 & 4.6 & 4.8 & 2.1 & 0.799 & 933 & 7.88 & 20 & 450 \\
\hline & $\mathrm{R}_{2}$ & $\mathrm{Na}-\mathrm{Cl}$ & 13.1 & 9.1 & 227.1 & 1.1 & 4.2 & 22.6 & 243.2 & 15.46 & 19,692 & 7.65 & 22 & 467 \\
\hline \multirow{2}{*}{$\begin{array}{l}\text { December } \\
2013\end{array}$} & $\mathrm{R}_{1}$ & $\mathrm{Mg}_{-} \mathrm{SO}_{4}$ & 4.0 & 7.2 & 1.7 & 0.1 & 4.4 & 6.0 & 2.0 & 0.838 & 960 & 8.1 & 16 & 560 \\
\hline & $\mathrm{R}_{2}$ & $\mathrm{Na}-\mathrm{Cl}$ & 7.6 & 11.1 & 172.1 & 1.0 & 4.3 & 11.3 & 162.6 & 10.78 & 13,728 & 7.6 & 18 & 584 \\
\hline \multirow{2}{*}{$\begin{array}{c}\text { January } \\
2014\end{array}$} & $\mathrm{R}_{1}$ & $\mathrm{Mg}-\mathrm{HCO}_{3}$ & 3.5 & 3.8 & 1.1 & 0.1 & 5.0 & 2.0 & 0.9 & 0.577 & 667 & 7.8 & 10 & 1,340 \\
\hline & $\mathrm{R}_{2}$ & $\mathrm{Na}-\mathrm{Cl}$ & 12.6 & 10.1 & 110.6 & 0.5 & 4.9 & 15.0 & 120.7 & 8.19 & 10,433 & 7.7 & 13 & 1,425 \\
\hline \multirow{2}{*}{$\begin{array}{c}\text { February } \\
2014\end{array}$} & $\mathrm{R}_{1}$ & $\mathrm{Ca}-\mathrm{HCO}_{3}$ & 5.5 & 2.5 & 1.6 & 0.1 & 4.3 & 3.5 & 1.7 & 0.674 & 750 & 7.9 & 16 & 875 \\
\hline & $\mathrm{R}_{2}$ & $\mathrm{Na}-\mathrm{Cl}$ & 12.6 & 16.1 & 148.8 & 0.7 & 4.2 & 17.9 & 155.5 & 10.46 & 13,325 & 7.7 & 18 & 922 \\
\hline \multirow{2}{*}{$\begin{array}{c}\text { March } \\
2014\end{array}$} & $\mathrm{R}_{1}$ & $\mathrm{Mg}-\mathrm{HCO}_{3}$ & 3.4 & 5.2 & 1.3 & 0.1 & 5.5 & 4.2 & 1.1 & 0.743 & 843 & 7.8 & 20 & 1,419 \\
\hline & $\mathrm{R}_{2}$ & $\mathrm{Na}-\mathrm{Cl}$ & 7.0 & 14.5 & 88.0 & 0.5 & 4.8 & 5.6 & 89.6 & 6.2 & 7,800 & 7.5 & 21 & 1,470 \\
\hline \multirow{2}{*}{$\begin{array}{l}\text { April } \\
2014\end{array}$} & $\mathrm{R}_{1}$ & $\mathrm{Mg}-\mathrm{HCO}_{3}$ & 3.5 & 4.8 & 1.4 & 0.1 & 4.7 & 4.3 & 1.0 & 0.695 & 886 & 7.8 & 24 & 695 \\
\hline & $\mathrm{R}_{2}$ & $\mathrm{Na}-\mathrm{Cl}$ & 15.0 & 20.0 & 154.5 & 0.6 & 4.5 & 17.0 & 160.3 & 10.93 & 13,801 & 7.6 & 24 & 770 \\
\hline \multirow{2}{*}{$\begin{array}{l}\text { May } \\
2014\end{array}$} & $\mathrm{R}_{1}$ & $\mathrm{Mg}-\mathrm{SO}_{4}$ & 4.0 & 5.2 & 1.6 & 0.1 & 4.6 & 5.1 & 1.3 & 0.757 & 854 & 7.75 & 26 & 505 \\
\hline & $\mathrm{R}_{2}$ & $\mathrm{Na}-\mathrm{Cl}$ & 13.3 & 14.7 & 290.2 & 1.5 & 4.4 & 15.3 & 297.0 & 18.52 & 23,586 & 7.8 & 27 & 510 \\
\hline \multirow{2}{*}{$\begin{array}{l}\text { June } \\
2014\end{array}$} & $\mathrm{R}_{1}$ & $\mathrm{Mg}-\mathrm{SO}_{4}$ & 4.1 & 6.6 & 2.1 & 0.1 & 4.7 & 7.3 & 1.8 & 0.923 & 1,060 & 8.1 & 30 & 130 \\
\hline & $\mathrm{R}_{2}$ & $\mathrm{Na}-\mathrm{Cl}$ & 12.7 & 13.2 & 368.8 & 2.8 & 4.3 & 15.4 & 386.0 & 23.38 & 29,783 & 7.9 & 29 & 135 \\
\hline
\end{tabular}

Table 4. Average halite concentration and halite mass of the different water sources feeding the Firoozabad River.

\begin{tabular}{|l|c|c|c|c|}
\hline \multicolumn{1}{|c|}{ Water resources } & $\begin{array}{c}\text { Volume of } \\
\text { water } \mathbf{( m}^{\mathbf{3}} \mathbf{)}\end{array}$ & $\begin{array}{c}\text { Average halite } \\
\text { concentration } \mathbf{( m g} / \mathbf{1})\end{array}$ & $\begin{array}{c}\text { Halite mass } \\
\text { (Tons) }\end{array}$ & $\begin{array}{c}\text { Percentages of } \\
\text { halite mass (\%) }\end{array}$ \\
\hline FR $\left(\mathrm{R}_{1}\right)$ & $16,796,160$ & 100 & 1,680 & 0.8 \\
\hline $\begin{array}{l}\text { Runoff from part } \\
\text { of the JSD }\end{array}$ & 233,280 & 4,000 & 933 & 0.5 \\
\hline Narak Creek & 466,560 & 440 & 205 & 0.1 \\
\hline $\begin{array}{l}3 \text { Brine springs } \\
\left(\mathrm{SB}_{1}, \mathrm{SB}_{2}, \text { and } \mathrm{SB}_{3}\right)\end{array}$ & 163,300 & 314,000 & 51,250 & 24 \\
\hline $\begin{array}{l}\text { Direct dissolution } \\
\text { by the FR }\end{array}$ & - & 9,475 & 159,037 & 74.6 \\
\hline FR $\left(\mathrm{R}_{2}\right)$ & $17,659,300$ & 12,070 & 213,150 & $\sum=100$ \\
\hline
\end{tabular}

\section{CONCLUSIONS}

Comprehensive understanding of the many diapirs of Hormuz salt emerging on the surface of the Zagros Mountains requires detailed hydrogeological studies as well as combining these results with the many tectonic and morphological studies that already exist.

The JSD landscape and karst development are controlled by several parameters. These include the rate of the JSD salt extrusion relative to dissolution rate of that salt, the time elapsed since the salt first surfaced, tectonic activities of the Zagros Mountains, ground surface slope, the extremely low permeability of salt rocks still flowing tens of meters beneath the ground surface, the emergence of springs above the local base of erosion, high salt concentrations (up to $320 \mathrm{~g} / 1$ ) and rapid water saturation with respect to halite. The salt actively extruding in the vent area is diapiric gneissose salt, destressing and expanding without any protection by soil or vegetation. The cap soil thickens as more and more of the extruded salt is dissolved the longer time it is on the surface. The high standing vent area indicates that the extrusion rate of the salt diapir (2-3 $\mathrm{m} \mathrm{a}^{-1}$; Talbot et al., 2000) is significantly higher than the rates of dissolution and erosion of the salt and its Phanerozoic country rocks. Salt is only exposed on slopes sufficiently steep for the soil to slide and/or be washed downslope. Groundwater generally flows along the strike of the many carbonates karst terrains in the Zagros Mountains and is controlled mainly by local structure, exposed stratigraphy and base of erosion (Ashjari \& Raeisi, 2006; Raeisi, 2008). Most of the exposed salt bodies tower above their surroundings so that the only water on and in them is supplied by precipitation from above. As soon as the salt reaches the surface (at rates that can be over $1 \mathrm{~m} \mathrm{a}^{-1}$ : Talbot et al., 2000) it expands (dilates) by fracturing on a variety of scales to a porous and permeable surficial brittle zone that is a few meters thick over the crest of every salt fountain in Iran but thickens downslope to maxima near $\sim 100 \mathrm{~m}$. Precipitation draining through and dissolving the outer veneer of dilated salt leaves a residual blocky cap soil of the insoluble components within it (mainly gypsum with a few silicates). By the time the precipitation (now groundwater) drains through the brittle zone it is already saturated in $\mathrm{NaCl}$. Incapable of further salt dissolution, such brines drain over the non-dilated, impermeable, still- 
confined and still flowing salt and emerge downslope at brine springs above the local base of erosion. The lack of preferred directional distribution of sinkholes and brine springs all over the JSD indicates that the fabric of the flowing salt does not control the patterns of salt karst.

Inherited sinkholes enlarge and are joined by new collapse sinkholes as the cap soils thicken by further dissolution as salt flow carries them downslope. Two main categories of caves were recognized in the JSD: stream passages and shaft-related caves. Stream passages develop at the downstream ends of blind valleys with temporary streams of $\mathrm{NaCl}$-unsaturated waters collected in basins floored by thick cap soils. Shafts and shaft-related caves develop by subsurficial corrosion into circular sinkholes, often with small water input due to rapid corrosion by a film flow (Frumkin, 1994). Most caves on the JSD salt are inlet caves and vertical shafts supply large volumes of surface water to subsurface spaces filled by sediment and debris, from which the water is slowly released to springs.

The FR has cut a deep gorge through the northern end of the JSD. The south side of this impressive gorge is bounded by very unstable salt cliffs over $800 \mathrm{~m}$ high, that probably collapse during most wet seasons to temporary dam the entire river and lead to dangerous floods when each dam fails. This may be a unique phenomenon in Iran although smaller streams sculpt parts of the margins of other salt diapirs. The FR dissolves significant amounts of halite from the JSD, in the order of about 215,000 ton/a, increasing the TDS of $\sim 23.9$ million $\mathrm{m}^{3} \mathrm{a}^{-1}$ of river water from $800 \mathrm{mg} / 1$ to $13,500 \mathrm{mg} / 1$. A relocation of the FR channel would significantly enhance the quality of river water downstream. However, such redirection is not recommended because it would disrupt the considerable beauty of the natural environment hereabouts and reduce the chance of success of any proposal nominating the JSD and its surroundings as a natural world heritage site.

\section{ACKNOWLEDGMENTS}

The authors would like to acknowledge the Research Council of Shiraz University for their support. The research was made also within research project no. RVO67985831 of the Institute of Geology of the CAS.

\section{REFERENCES}

Ahmadzade Heravi M., Houshmandzadeh M. \& Nabavi M., 1990 - New concept of Hormoz Formation's stratigraphy and the problem of salt diapirism in south Iran. Proceedings of the Symposium on Diapirism with Special Reference to Iran, Tehran, Iran. Geological Survey of Iran, 1: 1-21.

Ashjari J. \& Raeisi E., 2006 - Influences of anticlinal structure on regional flow, Zagros, Iran. Journal of Cave and Karst Studies, 68: 118-129.

Bosák P., Jaroš J., Spudil J., Sulovský P. \& Václavek V., 1998 - Salt plugs in the eastern Zagros, Iran: results of regional geological reconnaissance. GeoLines (Praha), (7): 3-174.
Bosák P., Bruthans J., Filippi M., Svoboda T. \& Šmíd J., 1999 - Karst and caves in salt diapirs, SE Zagros Mts. (Iran). Acta Carsologica, 28 (2): 41-75.

Bruthans J., Smid J., Filippi M. \& Zeman O., 2000 Thickness of caprock and other important factors affecting morphogenesis of salt karst. Acta Carsologica, 29 (2): 51-64.

Bruthans J., Filippi M., Kolčava M. \& Palatinus P., 2004 - Expedice NAMAK 2004 aneb Írán už nebude jako dřiv? Speleofórum '04, 23: 65-70.

Bruthans J., Filippi M., Zare M., Asadi N. \& Vilhelm Z., 2006 - 3N Cave: the longest salt cave in the world. National Speleological Society News, 64 (9): 10-18.

Bruthans J., Asadi N., Filippi M., Vilhelm Z. \& Zare M., 2008 - A study of erosion rates on salt diapir surfaces in the Zagros Mountains, SE Iran. Environmental Geology, 53: 1079-1089.

https://doi.org/10.1007/s00254-007-0734-6

Bruthans J., Filippi M., Asadi N., Zare M., Šlechta S. \& Churáčková Z., 2009 - Surficial deposits on salt diapirs (Zagros Mountains and Persian Gulf Platform, Iran): Characterization, evolution, erosion and the influence on landscape morphology. Geomorphology, 107 (3): 195-209.

https://doi.org/10.1016/j.geomorph.2008.12.006

Bruthans J., Filippi M., Zare M., Churáčková Z., Asadi N., Fuchs M. \& Adamovič J., 2010 - Evolution of salt diapir and karst morphology during the last glacial cycle: effects of sea-level oscillation, diapir and regional uplift, and erosion (Persian Gulf, Iran). Geomorphology, 121: 291-304.

https://doi.org/10.1016/j.geomorph.2010.04.026

Bruthans J., Kamas J., Filippi M., Zare M. \& Mayo A.L., 2017 - Hydrogeology of salt karst under different cap soils and climates (Persian Gulf and Zagros Mts., Iran). International Journal of Speleology, 46 (2): 303-320. https://doi.org/10.5038/1827-806X.46.2.2109

Calaforra J.M. \& Pulido Bosch A., 1999 - Gypsum karst features as evidence of diapiric processes in the Betic Cordillera, Southern Spain. Geomorphology, 29: 251-264. https://doi.org/10.1016/S0169-555X(99)00019-7

Edalatnia Z., Alavi A., Jahani S. \& Dehbashi Ghanavati N., 2012 - The effect of the Jahani Salt Diapir rising on the adjacent strata and structures. In: Zarei M. (Ed.), Proceeding of the $16^{\text {th }}$ National Conference of Geological Society of Iran, Shiraz (in Persian).

Falcon N.L., 1974 - Southern Iran: Zagros Mountains. Geological Society, London, Special Publications, 4 (1): 199-211.

https://doi.org/10.1144/GSL.SP.2005.004.01.11

Filippi M., Bruthans J. \& Svoboda T., 2006 - Expedice NAMAK 2005. Speleofórum '06, 25: 46-51.

Filippi M., Bruthans J., Palatinus L., Zare M. \& Asadi N., 2011 a - Secondary halite deposits in the Iranian salt karst: general description and origin. International Journal of Speleology, 40 (2): 141-162.

https://doi.org/10.5038/1827-806X.40.2.7

Filippi M., Jäger O., Bruthans J. \& Šlechta S., 2010 Expedice Namak 2009: Nová motivace. Speleofórum '10, 2: 34-42 (in Czech with English abstract).

Filippi M., Jäger O., Bruthans J., Slechta S. \& Palatinus L., 2011b - NAMAK 2010: Prodlužování Jeskyně 3N a Kóta $4000 \mathrm{~cm}$. Speleofórum '11, 30: 52-62.

Filippi M., Bruthans M., Jager O., Zare M. \& Asadi N., 2013 - Project NAMAK: Some of the most spectacular findings in the Iranian salt karst. In: Filippi M. \& Bosák P. (Eds.), Proceedings of the $16^{\text {th }}$ International Congress of Speleology, July 21-28, Brno, 3: 48-53. 
Frumkin A., 1994 - Hydrology and denudation rates of halite karst. Journal of Hydrology, 162 (1): 171-189. https://doi.org/10.1016/0022-1694(94)90010-8

Frumkin A., 2000 - Speleogenesis in salt the Mount Sedom area, Israel. In: Klimchouk A., Ford D.C., Palmer A.N. \& Dreybrodt W. (Eds.), Speleogenesis. Evolution of karst aquifers. National Speleological Society, Huntsville, p. 443-451.

Hamlin H.S., 2006 - Salt domes in the Gulf Coast aquifer. In: Mace R.E., Davidson S.C., Angle E.S. \& Mullican W.F. (Eds.), Aquifers of the Gulf Coast of Texas. Texas Water Development Board, Report 365, p. 217-230.

James G. \& Wynd J., 1965 - Stratigraphic nomenclature of Iranian oil consortium agreement area. AAPG Bulletin, 49 (12): 2182-2245.

Johnson K.S. 1997 - Evaporite karst in the United States. Carbonates and Evaporites, 12 (1): 2-14. https://doi.org/10.1007/BF03175797

Kent P.E., 1958 - Recent studies of south Persian salt plugs. American Association of Petroleum Geologists Bulletin, 422: 2951-2972.

Kent P.E., 1970 - The salt plugs of the Persian Gulf region. Transactions of the Leicester Literary \& Philosophical Society, 64: 56-88.

Kent P.E., 1979 - The emergent Hormuz salt plugs of southern Iran. Journal of Petroleum Geology, 2: 117-144. https://doi.org/10.1111/j.1747-5457.1979.tb00698.x

Lucha P., Cardona F., Gutiérrez F. \& Guerrero J., 2008 Natural and human-induced dissolution and subsidence processes in the salt outcrop of the Cardona Diapir (NE Spain). Environmental Geology, 5 (53): 1023-1035. https://doi.org/10.1007/s00254-007-0729-3

Mehdizadeh R., Zarei M. \& Raeisi, E., 2015 - How subaerial salt extrusions influence water quality in adjacent aquifers. Journal of Hydrology, 531: 1108-1113. https://doi.org/10.1016/j.jhydrol.2015.11.021

Nekouei E. \& Zarei M., 2016 - Karst hydrogeology of Karmustadj salt diapir, southern Iran. Carbonates and Evaporites, 32 (3): 315-323.

https://doi.org/10.1007/s13146-016-0298-1

Nekouei E., Zarei M. \& Raeisi E., 2016 - The influence of diapir brine on groundwater quality of surrounding aquifers, Larestan, Iran. Environmental Earth Sciences, 75 (7): 1-13.

https://doi.org/10.1007/s12665-015-5237-2

Parkhurst D.L. \& Appelo C., 1999 - User's guide to PHREEQC (Version 2): a computer program for speciation, batch-reaction, one dimensional transport, and inverse geochemical calculations.

Raeisi E., 2008 - Ground-water storage calculation in karst aquifers with alluvium or no-flow boundaries. Journal of Cave and Karst Studies, 70: 62-70.

Raeisi E., Jehbez O. \& Moore F., 1996 - Hydrochemical behavior ofkarstic and evaporitic formations surrounding Sarvestan Plain. Theoretical and Applied Karstology, 9: 165-174.

Rodríguez-Estrella T. \& Pulido-Bosch A., 2010 - Gypsum karst evolution in a diapir: a case study. (Pinoso, Alicante, Spain). Environmental Earth Sciences, 59: 1057-1063.

https://doi.org/10.1007/s12665-009-0097-2

Sharafi A., Raeisi E. \& Farhoodi G., 2002 - The Effect of Darab Salt Dome on the Quality of Adjacent Karst and Alluvium Aquifers (South of Iran). Acta Carsologica, 31 (2): 105-113.
Stocklin J., 1968 - Salt deposits of the Middle East. Geological of Society America Special Papers, 88: 157-181. https://doi.org/10.1130/SPE88-p157

Talbot C.J., 1979 - Fold trains in a glacier of salt in southern Iran. Journal of Structural Geology, 1: 5-18. https://doi.org/10.1016/0191-8141(79)90017-8

Talbot C.J., 1998 - Extrusions of Hormuz salt in Iran. Geological Society, London, Special Publications, 143 (1): 315-334.

https://doi.org/10.1144/GSL.SP.1998.143.01.21

Talbot C.J. \& Jarvis R.J., 1984 - Age, budget and dynamics of an active salt extrusion in Iran. Journal of Structural Geology, 6 (5): 521-533. https://doi.org/10.1016/0191-8141(84)90062-2

Talbot C. \& Alavi M., 1996 - The past of a future syntaxis across the Zagros. Geological Society, London, Special Publications 100 (1): 89-109. https://doi.org/10.1144/GSL.SP.1996.100.01.08

Talbot C.J., Medvedev S., Alavi M., Shahrivar H. \& Heidari, E., 2000 - Salt extrusion at Kuh-e-Jahani, Iran, from June 1994 to November 1997. Geological Society, London, Special Publications, 174 (1): 93-110. https://doi.org/10.1144/GSL.SP.1999.174.01.06

Talbot C.J., Farhadi R. \& Aftabi P., 2009 - Potash in salt extruded at Sar Pohl diapir, Southern Iran. Ore Geology Reviews, 35 (3): 352-366.

https://doi.org/10.1016/j.oregeorev.2008.11.002

Tayebi M.H., Tangestani M. H. \& Roosta H., 2013 Mapping salt diapirs and salt diapir-affected areas using MLP neural network model and ASTER data. International Journal of Digital Earth, 6 (2): 143-157. https://doi.org/10.1080/17538947.2011.606336

Yari S., 2017 - The Fate of Saline Water and Salinity Reduction by Hydrogeological Methods in the Catchment Area of Mond River. Unpublished MS thesis, Shiraz University, $530 \mathrm{p}$.

Zarei M., 2015 - Factors governing the impact of emerged salt diapirs on water resources. Groundwater, 54 (3): 354-362. https://doi.org/10.1111/gwat.12370

Zarei M. \& Raeisi E., 2010a - Conceptual modeling of brine flow into aquifers adjacent to the Konarsiah salt diapir, Iran. Cave and Karst Science, 37 (2): 37-44.

Zarei M. \& Raeisi E., 2010b - Karst development and hydrogeology of Konarsiah salt diapir, south of Iran. Carbonates and evaporites, 25 (3): 217-229. https:// doi.org/10.1007/s13146-010-0027-0

Zarei M., 2010c-Hydrogeology of salt diapirs in the south of Iran. Unpublished Ph.D. thesis, Shiraz University, 193 p.

Zarei M., Raeisi E. \& Talbot C., 2011 - Karst development on a mobile substrate: Konarsiah salt extrusion, Iran. Geological Magazine, 149 (3): 412-422. https://doi.org/10.1017/S0016756811000689

Zarei M., Raeisi E., Merkel B.J. \& Kummer N.A., 2012 Identifying sources of salinization using hydrochemical and isotopic techniques, Konarsiah, Iran. Environmental Earth Sciences, 70: 587-604. https://doi.org/10.1007/s12665-012-2143-8

Zarei M., E. Raeisi \& Mahmoudi K., 2013 - The impact of salt diapirs on the quality of carbonate karst waters, Bastak, Iran. Environmental Earth Sciences, 71 (9): 3893-3906. https://doi.org/10.1007/s12665-013-2775-3

Zarei M., Sedehi F. \& Raeisi E., 2014 - Hydrogeochemical characterization of major factors affecting the quality of groundwater in southern Iran, Janah Plain. Chemie der Erde-Geochemistry, 74 (4): 671-680. https://doi.org/10.1016/j.chemer.2014.03.005 